Int. J. Morphol.,

31(1):156-161, 2013.

\title{
Maternal Water Deprivation Affects the Spermatogenesis of the Offspring Rats
}

\author{
La Privación del Agua en la Etapa Materna de Ratas Afecta la Espermatogénesis de sus Crías
}

\author{
Shima Chehreie*; Arezou Rabzia** \& Mohammad Farhadi-mesterkhani***
}

CHEHREIE, S.; RABZIA, A. \& FARHADI-MESTERKHANI, M. Maternal water deprivation affects the spermatogenesis of the offspring rats. Int. J. Morphol., 31(1):156-161, 2013.

SUMMARY: Prenatal stresses such as water deprivation affect developmental process of embryo. This study evaluated the effects of water deprivation in pregnant mother on histological parameters of testis of offspring. Pregnant rats were divided into two groups (control and experimental). In experimental animals, water was removed from the ewes for $48 \mathrm{~h}$ at the end of third trimester of gestation (19-21 th days). Histopathology and histomorphic analysis and also TUNEL assay on offspring's testes were performed at pubertal age (60 days). The sperm motility either compared between two groups. The results showed that prenatal water deprivation induced histopathological alteration such as epithelium vacuolization, sloughing and detachments $(\mathrm{P}<0.01)$. Morphometrical data showed that prenatal water deprivation decreased tubular diameter and reduce epithelium height $(\mathrm{P}<0.01)$. Johnsen's score showed poor spermatogenesis in experimental group $(\mathrm{P}=0.001)$. The percent of germ cell apoptosis was increased in offspring's testes of rats born to mothers exposed to stress during pregnancy $(\mathrm{P}=0.000)$. The increased number of Multinucleated cells in the seminiferous lumen $(\mathrm{P}=0.000)$ in parallel with decreased number of sertoli cells $(\mathrm{P}=0.03)$ showed adverse effect of prenatal water deprivation on blood testis barrier. Present study revealed that prenatal water deprivation had injurious effect on developmental process of testes that affects on both germ cells and sertoli cells and had noxious effect on sperm parameters. These data confirm that prenatal stress disrupts normal spermatogenesis of offspring.

KEY WORDS: Prenatal stress; Rat; Testis; Water deprivation.

\section{INTRODUCTION}

Epidemiological studies have demonstrated that maternal exposure to prenatal stress can lead to permanent modification of hypothalamo-pituitary-adrenal (HPA) function and stress-related behaviors in offspring (Tollenaar et al., 2011; Whriledge \& Cidlowski, 2010).

This endocrine effect of maternal stress is revealed by in vivo studies. In rats, although large component of the brain develops later on postnatal period (Dobbing \& Sands, 1979), maternal stress can also affect HPA axis activity as the same as shown in Rhesus macaques (Schneider et al., 2004), guinea pigs (Kapoor \& Matthews, 2011) and mice (Schmidt et al., 2002).

Testosterone as an inhibitor of HPA axis modulates behavior. It have been demonstrated that prenatal stress reduces the level of testosterone in male rats and guinea pigs but not for mice born to mothers exposed to stress during pregnancy (Crump \& Chevins, 1989; Richardson et al., 2006).

The third trimester of gestation that is the period of rapid brain myelination and occurrence of fetal brain growth spurt is critical period of time for exposure to prenatal stress on HPA axis (Ohkawa et al., 1991; Maccari et al., 2003; Schmidt et al.).

Maternal stress in this period can also affect behavior of female guinea pigs and also male mice offspring (Crump et al.; Richardson et al.). Furthermore, we showed that the stress derived by prenatal water deprivation during third trimester of gestation leaded to decrease in the level of testosterone and induced apoptosis in sexual related area of the brain of offspring rats (Chehreie et al., 2011).

\footnotetext{
* Biology department, Islamic Azad University, Arak Branch, Arak, Iran.

${ }^{* * *}$ M.Sc. Student of cellular and molecular Biology, Fertility and Infertility Research Center, Kermanshah University of Medical Sciences, Kermanshah, Iran. ${ }^{* * *}$ Student of Medicine, Student Research Committee, Kermanshah University of Medical Sciences, Kermanshah, Iran.
} 
Herein the study we aimed to demonstrate if the stimulation of HPA axis as a consequence of decreased testosterone could affect genital development of male rats born to mothers exposed to stress during pregnancy. For this purpose, sperm parameters, histological characteristics of testis were evaluated. TUNEL assay was also performed for showing the occurrence of apoptosis in the testes.

\section{MATERIAL AND METHOD}

Experimental design. Twenty inbred pregnant SpragueDawley rats aged 6-8 weeks ( $250 \pm 5 \mathrm{~g}$ ) were obtained from a closed bred colony at Islamic Azad University. The animals were adapted and maintained in an air-conditioned animal house at temperature of $23 \pm 2^{\circ} \mathrm{C}$, relative humidity at $50 \%$ and photo -cycle 12:12 h light and dark period. The animals were provided with standard diet pellet and water ad libitum. All experiments were carried out according to the guidelines of animal care and use committee of at our university.

The rats were divided randomly into two control and experimental groups $(\mathrm{n}=10)$. For the experimental animals, water was removed from the ewes for $48 \mathrm{~h}$ at the end of third trimester of the gestation (19-21 days). The newborns housed in normal conditions as that for their parents. After 2 months, pubertal rats of two groups (40 pups per each group) were weighed and were anesthetized with ethyl ether and killed by decapitation. The testes were removed and weighed. Then, $5 \mu \mathrm{m}$ histological sections were achieved from paraffin blocks of left testes. The sections stained with Hematoxilin and Eosin and also with terminal deoxynucleotidyl transferase (TdT)-mediated deoxy-UTP nick end labeling (TUNEL) as previously described (Chehreie et al.).

Sperm parameters assessment. The left caudae epididymis were also dissected and were kept for $30 \mathrm{~min}$ at $37^{\circ} \mathrm{C}$ to promote the release of sperm into the Petri dish containing Dulbecco's Modified Eagle Medium: Nutrient Mixture F-12 (DMEM/F-12). Then, sperm were collected with a micropipette (aliquot $20 \mu \mathrm{l}$ ) on a slide for motility analysis. Sperm motility was determined by counting all progressive sperm, the non-progressive and the immotile sperm in the same field. In each preparation, at least 200 sperm was counted. This motility assessment was repeated in a new preparation from the same semen sample (Kurdoglu et al., 1994).

Histopathology. The sign of germ cell degeneration were examined in nearly 150 seminiferous tubules and the criteria were included following alterations:
1) Detachment: appearance of breaking off cohort of spermatocyte from the seminiferous epithelium.

2) Sloughing: release of clusters of germ cell into the lumen of seminiferous tubule.

3) Vacuolization: appearance of empty space in the seminiferous tubule.

4) Presence of multinucleated giant cells within the lumen the seminiferous epithelium (Orazizadeh et al., 2010).

Morphometry. For this purpose we measured the external diameter and the lumen diameter of 150 seminiferous tubules per animal by fitting a graticule of a calibrated linear scale in the $\times 10$ eyepiece of Leitz microscope at objective lens $\times 40$ using of calibrated Motic software. For measuring the height of seminiferous epithelium, the tubular diameter was subtracted from luminar diameter (Orazizadeh et al.).

Maturity of germ line epithelium. About 100 tubules per animal were evaluated for determining the maturity of germ line epithelium by X10 objective lens and Johnson's score was served for this propose (Johnsen, 1970).

Number of Sertoli cells per seminiferous tubule. To evaluate the possible effects of in utero and lactational growth restriction on the process of proliferation of Sertoli cells, all the nuclei of Sertoli cells were counted in histological sections of the testis of 60-days-old rats, in 20 seminiferous tubules per rat at stage VII of spermatogenesis as previously described (Amorim et al., 2011; Kotaja et al., 2004). The evaluations were accomplished in a blind assay (without knowledge of the group to which each animal may belong).

TUNEL Assay. Apoptosis was assessed by terminal deoxynucleotidyl transferase (TdT)- mediated deoxy-UTP nick end labeling (TUNEL) assay by using In Situ Cell Death Detection Kit, AP (RocheDiagnostics Deutschland GmbH, Germany; 16848091).

The paraffin sections were dewaxed and rehydrated by standard methods. Proteases were added and incubated with $5 \%$ of appropriate normal serum for $30 \mathrm{~min}$ at $37^{\circ} \mathrm{C}$. The slides were washed in phosphate buffered saline (PBS). The sections were permeabilised ( $2 \mathrm{~min}$, on ice) and incubated with TUNEL reaction mixture $\left(60 \mathrm{~min}, 37^{\circ} \mathrm{C}\right)$. Anti-fluorescein-AP was added and incubated $(30 \mathrm{~min}$, $37^{\circ} \mathrm{C}$ ). Contra staining was undertaken with propidium Iodide (PI; $1 \mu \mathrm{g} \mathrm{ml}-1$ ). Apoptotic index (AI) was calculated by dividing the number of TUNEL-positive cells to total number of the cells in randomly focused fields, and the result was multiplied by 100 (Lirdi et al., 2008). 
Statistical analysis. All data were analyzed using Sigma Stat (SPSS Inc, Chicago, Illinois). Differences between groups were examined for statistical significance using Paired T- test $(\mathrm{p}<0.05)$. The data are presented as means \pm SEM.

\section{RESULTS}

No death was observed among two groups during the period of the study. There were significant reduction in total body weight $(\mathrm{P}=0.03)$, the weight of testes $(\mathrm{P}=0.04)$ and also in total sperm motility and progressive sperm motility $(\mathrm{P}<0.01)$ in rats born to mothers exposed to water deprivation during pregnancy (Table I A and $\mathrm{B}$ ).
Hitopathology and Maturity of the germinal epithelium. Histological analysis of H\&E stained sections of testes showed high incidence of Vacuolated, sloughed and detached seminiferous tubules (Fig. 1) and apoptotic (Fig. 2), also high ratio of apoptotic index in experimental group $(\mathrm{P}<0.001)$ (Table IB). The apoptotic index in experimental group $(21 \pm 0.4)$ was significantly increased in comparison with control group (1.2 \pm 0.6$)(\mathrm{P}=0.000)$. Johnsen's score in control group was $8.23 \pm 0.3$ and for experimental group it was $4.26 \pm 0.8$ that represented significant reduction in experimental group $(\mathrm{P}=0.001)$. The external diameter and the height of the epithelium of seminiferous tubules either significantly reduced in experimental group $(\mathrm{P}<0.001)$ (Table IC).

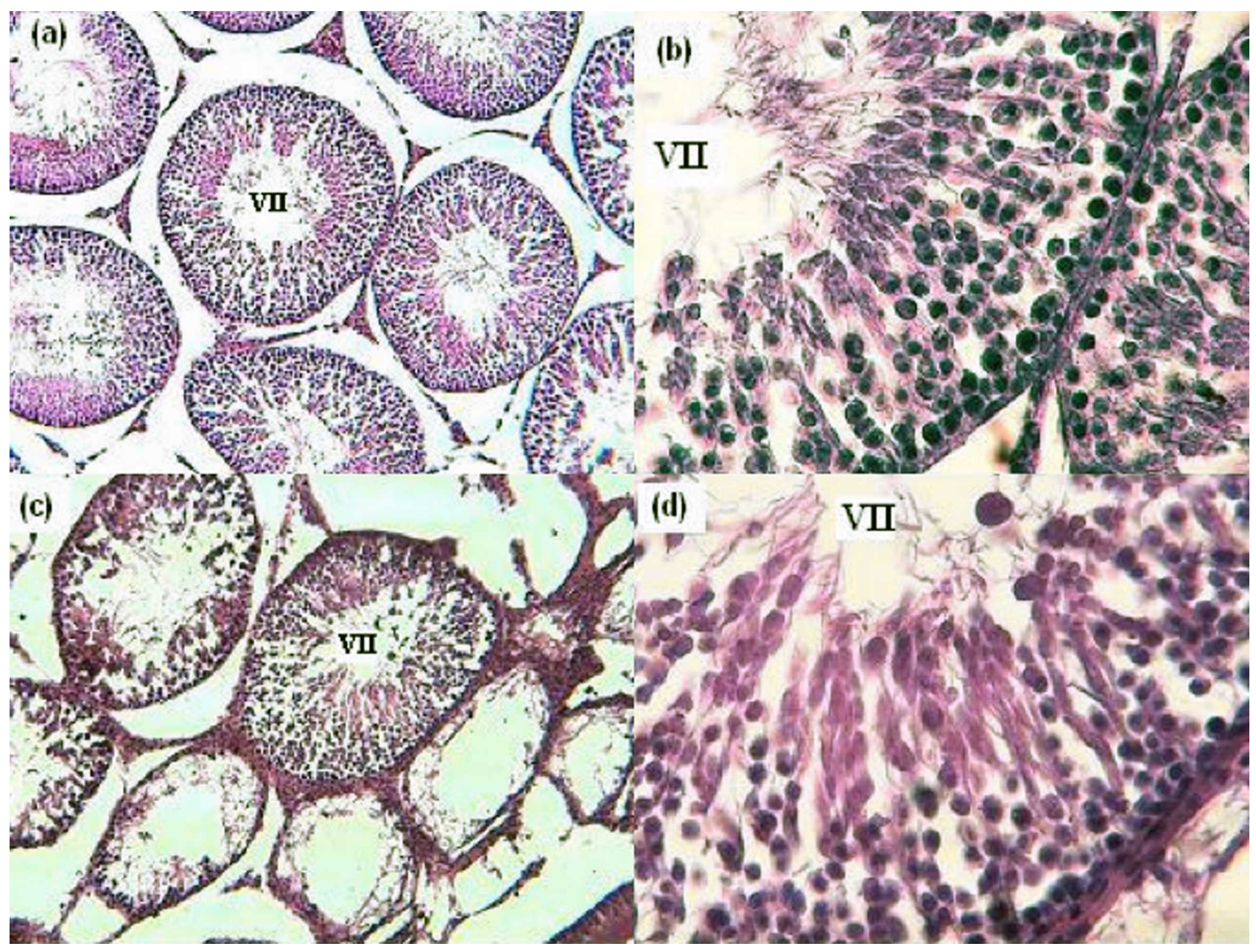

Fig. 1. Light microscopy of cross sections of H\&E stained testis. (a, b): Control group; (c, d) Prenatal water derivate group. Regular seminiferous tubules (a) contained high amounts of sperm. Irregular seminiferous tubules (c) contained low amounts of sperm. The tubules showed different amounts of vacuolization, atrophy, detachment and slugging. Higher magnification (b, d) of the pictures brought to show the stage VII of spermatogenesis for evaluation of sertoli cells and also for showing multinucleated giant cell (d) (Magnifications: a, $c=X 10 ; b, d=X 40)$. 
Table I. Morphometric and histopathological parameters of testis and sperm in control and prenatal water deprivate (Experimental) rats. A. Total body and testis weight. B. Histological characteristics, Apoptotic Index and Johnsen's score of the tubules and Sperm motility. C. The diameters of the Seminiferous tubules. (The values are shown as mean \pm S.D, $* \mathrm{P}<0.05$, $* * \mathrm{p}<0.01$ )

\begin{tabular}{lccc}
\hline \multirow{2}{*}{ P- Value } & \multicolumn{2}{c}{ Group } & Parameter \\
\cline { 2 - 3 } & Experimental & Control & \\
\hline $0.03^{*}$ & $210 \pm 4.1$ & $255 \pm 3.3$ & Total body weight $(\mathrm{g})$ \\
$0.04^{*}$ & $0.5 \pm 0.33$ & $0.7 \pm 0.21$ & Testis weight $(\mathrm{g})$ \\
\hline
\end{tabular}

\begin{tabular}{|c|c|c|c|}
\hline \multirow{2}{*}{ P-Value } & \multicolumn{2}{|c|}{ Group } & \multirow{2}{*}{ Parameter } \\
\hline & Experimental & Control & \\
\hline $0.000 * *$ & $18 \pm 0.6$ & $90 \pm 0.2$ & Normal (\%) \\
\hline $0.000 * *$ & $20.4 \pm 0.8$ & $1.7 \pm 0.3$ & Detached $(\%)$ \\
\hline $0.000 * *$ & $15 \pm 0.4$ & $1.1 \pm 0.4$ & Sloughed $(\%)$ \\
\hline $0.000 * *$ & $44 \pm 0.1$ & $5.1 \pm 0.6$ & Vacuolated (\%) \\
\hline $0.000 * *$ & $3.2 \pm 0.4$ & 0 & Multinucleated (\%) \\
\hline $0.005 * *$ & $43 \pm 0.8$ & $78 \pm 0.4$ & Total sperm motility (\%) \\
\hline $0.007 * *$ & $28 \pm 0.6$ & $42 \pm 0.7$ & Progressive sperm motility (\%) \\
\hline $0.02 *$ & $17.0 \pm 0.4$ & $24.7 \pm 0.6$ & Sertoli cells per seminiferous (n) \\
\hline $0.000 * *$ & $21 \pm 0.4$ & $1.2 \pm 0.6$ & Apoptotic Index $(\%)$ \\
\hline $0.001 * *$ & $4.26 \pm 0.8$ & $8.23 \pm 0.3$ & Johnsen's score \\
\hline
\end{tabular}

\begin{tabular}{cccc}
\hline \multirow{2}{*}{ P- Value } & \multicolumn{2}{c}{ Group } & Parameter $(\boldsymbol{\mu m})$ \\
\cline { 2 - 3 } & Experimental & Control & \\
\hline $0.001^{* *}$ & $204.2 \pm 9$ & $285.7 \pm 8.1$ & External diameter \\
$0.001^{* *}$ & $98 \pm 11.5$ & $173.4 \pm 12.9$ & Epithelium height \\
\hline
\end{tabular}

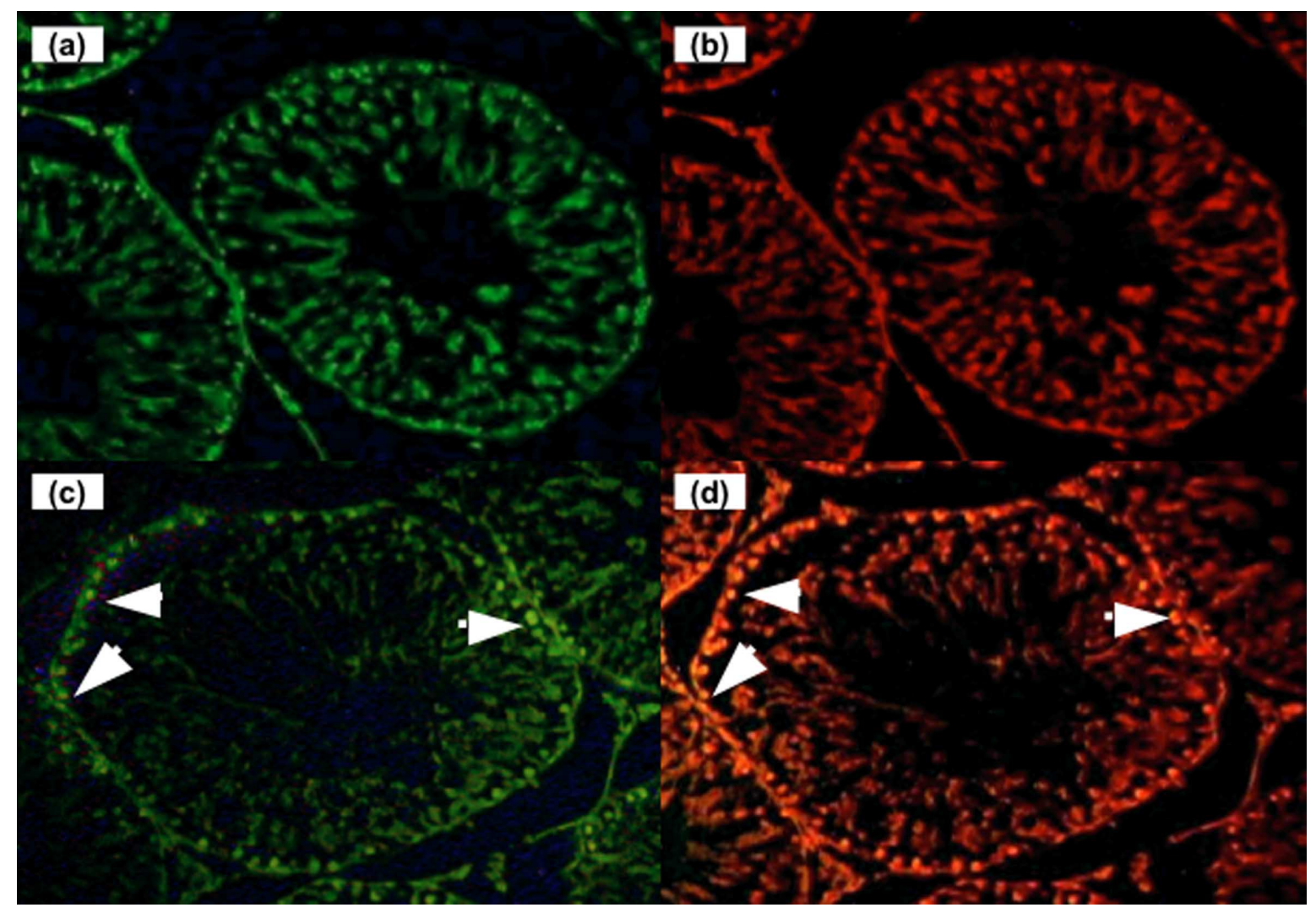

Fig. 2. Fluorescent microscopy of cross sections of TUNEL stained testis of rat in control group (a) and Prenatal water derivate group (c) and contra staining with Propidium Iodide (PI) (b, d). Apoptotic cells Show bright fluorescence nuclei indicated by arrowheads (Magnifications: X 20). 


\section{DISCUSSION}

In the present study the weights of pups born to mothers exposed to water deprivation during pregnancy reduced. These data were corroborating other studies both in rodents and human that showed maternal diabetes or prenatal restraint stresses induce low birth weight in newborns and remain small up to adulthood (Owen et al., 2005; Van Assche et al., 2001). The studies offer that maternal stress signals would change newborn phenotype up to adulthood by affecting hypothalamic-pituitary- adrenal (HPA) axis that leads surging maternal glucocorticoids to embryo through placental tissue (Mairesse et al., 2007). Moreover, maternal administration of dexamethasone, a synthetic glucocorticoid that readily crosses the placenta, reduces fetal growth in rats and in other mammals (Nyirenda et al., 1998; Seckl et al., 2004).

The study revealed that maternal water deprivation brings to decrease offspring's testis weight and also induced adverse effects on spermatogenesis.

Prenatal stress has been suggested to induce feminization and incomplete masculinization by affecting some dimorphic parts of the brain and spinal cord (Chehreie et al.; Grisham et al., 1992). It has also been revealed that prenatal stress blocks testosterone surge; during the critical stages of sexual differentiation on days 18-19 of gestation of rat, and thus induces the so-called 'prenatal stress syndrome' (Ward 1984).

To evaluate testicular toxicity we select some qualitative and quantitative criteria.

In present study we performed qualitative examination of germ cell morphometry by histopathology and quantitative examination by Johnson's scoring, morphometry, sperm motility and TUNEL assay (apoptosis index). Our data revealed that prenatal water deprivation resulting increase in vacoulation, detachment, degeneration of the germinal epithelium of seminiferuos tubules and also increasing number of TUNEL positive cells showed induction of germ cell apoptosis.

Other explanation of germ cell apoptosis is may be due to direct effect of glucocorticoids on certain specific gene activities and proteins, including Bcl-2 family, p53, and Fas (Sasagawa et al., 2001). However, the study demonstrated rupture of blood- testis barrier by degrading the number of sertoli cells, sloughing of immature germ cells and appearance of multinucleated giant cells in the lumen of seminiferuos tubules in prenatal water deprivated rats such as that shown in adults administrated to glucocorticoids (Orazizadeh et al.,) that confirm transients of these compounds from blood- testis barrier. On the other hand we previously showed that testosterone decreased following water deprivation. The reduction of testosterone is may be due to induction of apoptosis in central nervous system of pups (Chehrei et al.; Grisham et al.; Malaeb et al., 2009) or decreasing in susceptibility of testicular LH receptor and decreasing in testes production (Orr \& Mann, 1992).

Summing up, this study has established that prenatal water deprivation has cytotoxic and apoptotic effects on testicular germ cells. The transit of glucocorticoids from blood testis barrier, apoptotic effect of these compounds on the central nervous system that affect HPA axis in accompany with changing in regulatory receptors of testicular tissue are three possible pathways of toxicity of prenatal stress on spermatogenesis.

ACKNOWLEDGEMENT. This research was supported by a Grant (u-86044) research from council of the Islamic Azad University and Kermanshah University of Medical Sciences in 2011.

CHEHREIE, S.; RABZIA, A. \& FARHADI-MESTERKHANI, M. La privación del agua en la etapa materna de ratas afecta la espermatogénesis de sus crías. Int. J. Morphol., 31(1):156-161, 2013.

RESUMEN: El estrés prenatal, como la privación del agua, afecta el proceso de desarrollo embrionario. Este estudio evaluó los efectos de la falta de agua en la rata preñada sobre los parámetros histológicos del testículo de las crías. Las ratas preñadas fueron divididas en dos grupos (control y experimental). En los animales de experimentación, se eliminó el agua durante 48 h al final del término de la gestación (19-21 días). Junto al análisis histopatológico e histomorfométrico se realizó el ensayo TUNEL en los testículos de las crías en la edad puberal (60 días). La motilidad de los espermatozoides se comparó entre los dos grupos. Los resultados mostraron que la privación de agua prenatal induce alteraciones histopatológicas tales como vacuolización del epitelio, descamación y desunión $(\mathrm{P}<0,01)$. Los datos morfométricos mostraron que con la privación de agua prenatal hubo disminución del diámetro tubular y se redujo la altura del epitelio $(\mathrm{P}<0,01)$. El score de Johnsen mostró una espermatogénesis deficiente en el grupo experimental $(\mathrm{p}=0,001)$. El porcentaje de apoptosis de las células germinales se incrementó en los testículos de las crías de las ratas nacidas de madres expuestas a estrés durante el embarazo $(\mathrm{p}=0,000)$. Un aumento del número de células multinucleadas en el lumen seminífero $(\mathrm{P}=0,000)$ junto a la disminución del número de células de Sustento $(\mathrm{P}=0,03)$ demostró el efecto adverso de la privación de agua prenatal en la barrera hemato-testicular. El presente estudio reveló que la falta de agua prenatal tuvo un efecto perjudicial en el proceso de desarrollo de los testículos, lo que afecta a las células germinales y los sustentocitos, y tuvo un efecto nocivo sobre los parámetros seminales. Estos datos confirman que el estrés prenatal altera la espermatogénesis normal de la descendencia.

PALABRAS CLAVE: Estrés prenatal; Rata; Testículo; Privación de agua. 


\section{REFERENCES}

Amorim, E. M.; Damasceno, D. C.; Perobelli, J. E.; Spadotto, R.; Fernandez, C. D.; Volpato, G. T.; et al. Short- and long-term reproductive effects of prenatal and lactational growth restriction caused by maternal diabetes in male rats. Reprod. Biol. Endocrinol., 154(9):1-9, 2011.

Chehreie, S.; Sadri, S.; Khazaei, M.; Ghanbari, A.; Ayubian, M. \& Amiri, S. Prenatal water deprivation induce apoptosis in sexual dimorphic nucleus of the brain of male new born Sprague-Dawley rats. Int. J. Morphol., 29(2):496-500, 2011.

Crump, C. J. \& Chevins, P. F. Prenatal stress reduces fertility of male offspring in mice, without affecting their adult testosterone levels. Horm. Behav., 23(3):333-43, 1989.

Dobbing, J. \& Sands, J. Comparative aspects of the brain growth spurt. Early Hum. Dev., 3(1):79-83, 1979.

Grisham, W.; Casto, J. M.; Kashon, M. L.; Ward, I. L. \& Ward, O. B. Prenatal flutamide alters sexually dimorphic nuclei in the spinal cord of male rats. Brain Res., 578(1-2):69-74, 1992.

Johnsen, S. G. Testicular biopsy score count: a method for registration of spermatogenesis in human testis. Hormones, 1(1):2-25, 1970.

Kapoor, A. \& Matthews, S. G. Testosterone is involved in mediating the effects of prenatal stress in male guinea pig offspring. J. Physiol., 1589(Pt. 3):755-66, 2011.

Kotaja, N.; Kimmins, S.; Brancorsini, S.; Hentsch, D.; Vonesch, J. L.; Davidson, I.; et al. Preparation, isolation and characterization of stagespecific spermatogenic cells for cellular and molecular analysis. Nat. Methods, 1(3):249-54, 2004.

Kurdoglu, B.; Wilson, G.; Parchuri, N.; Ye, W. S. \& Meistrich, M. L. Protection from radiation induced damage to spermatogenesis by hormone treatment. Radiat. Res., 139(1):97-102, 1994.

Lirdi, L. C.; Stumpp, T.; Sasso-Cerri, E. \& Miraglia, S. M. Amifostine protective effect on cisplatin-treated rat testis. Anat. Res. (Hoboken), 291(7):797-808, 2008.

Maccari, S.; Darnaudery, M.; Morley-Fletcher, S.; Zuena, A. R.; Cinque, C. \& Van Reeth, O. Prenatal stress and long-term consequences: implications of glucocorticoid hormones. Neurosci. Biobehav. Rev., 27(1-2):119-27, 2003.

Mairesse, J.; Lesage, J.; Breton, C.; Bréant, B.; Hahn, T.; Darnaudéry, M.; et al. Maternal stress alters endocrine function of the fetoplacental unit in rats. Am. J. Physiol. Endocrinol. Metab., 292(6):E1526-33, 2007.

Malaeb, S. N.; Hovanesian, V.; Sarasin, M. D.; Hartmann, S. M.; Sadowska, G. B. \& Stonestreet, B. S. Effects of maternal antenatal glucocorticoid treatment on apoptosis in the ovine fetal cerebral cortex. J. Neurosci. Res., 87(1):179-89, 2009.

Nyirenda, M. J.; Lindsay, R. S.; Kenyon, C. J.; Burchell, A. \& Seckl, J. R. Glucocorticoid exposure in late gestation permanently programs rat hepatic phosphoenolpyruvate carboxykinase and glucocorticoid receptor expression and causes glucose intolerance in adult offspring. J. Clin. Invest., 101(10):2174-81, 1998.
Ohkawa, T.; Rohde, W.; Takeshita, S.; Dörner, G.; Arai, K. \& Okinaga, S. Effect of an acute maternal stress on the fetal hypothalamo-pituitaryadrenal system in late gestational life of the rat. Exp. Clin. Endocrinol., 98(2):123-9, 1991.

Orazizadeh, M.; Khorsandi, L. S. \& Hashemitabar, M. Toxic effects of dexamethason on mous testicular germ cell. Andrologia, 42(4):24753,2010 .

Orr, T. E. \& Mann, D. R. Role of glucocorticoids in the stress-induced suppression of testicular steroidogenesis in adult male rats. Horm. Behav., 26(3):350-63, 1992.

Owen, D.; Andrews, M. H. \& Matthews, S. G. Maternal adversity, glucocorticoids and programming of neuroendocrine function and behaviour. Neurosci. Biobehav. Rev., 29(2):209-26, 2005.

Richardson, H. N.; Zorrilla, E. P.; Mandyam, C. D. \& Rivier, C. L. Exposure to repetitive versus varied stress during prenatal development generates two distinct anxiogenic and neuroendocrine profiles in adulthood. Endocrinology, 147(5):2506-17, 2006.

Sasagawa, I.; Yazawa, H.; Suzuki, Y. \& Nakada, T. Stress and testicular germ cell apoptosis. Arch. Androl., 47(3):211-6, 2001.

Schmidt, M. V.; Oitzl, M. S.; Levine, S. \& de Kloet, E. R. The HPA system during the postnatal development of CD1 mice and the effects of maternal deprivation. Brain Res. Dev. Brain Res., 139(1):39-49, 2002.

Schneider, M. L.; Moore, C. F. \& Kraemer, G. W. Moderate level alcohol during pregnancy, prenatal stress, or both and limbic-hypothalamicpituitary-adrenocortical axis response to stress in rhesus monkeys. Child Dev., 75(1):96-109, 2004.

Seckl, J. R. Prenatal glucocorticoids and long-term programming. Eur. J. Endocrinol., 151 Supp. 3:U49-62, 2004.

Tollenaar, M. S.; Beijers, R.; Jansen, J.; Riksen-Walraven, J. M. \& de Weerth, C. Maternal prenatal stress and cortisol reactivity to stressors in human infants. Stress, 14(1):53-65, 2011.

Van Assche, F. A.; Holemans, K. \& Aerts, L. Long-term consequences for offspring of diabetes during gestation. Br. Med. Bull., 60:173-82, 2001.

Ward, I. L. The prenatal stress syndrome: current status. Psychoneuroendocrinology, 9(1):3-11, 1984.

Whirledge, S. \& Cidlowski, J. A. Glucocorticoids stress and fertility. Minerva Endocrinol., 35(2):109-25, 2010.

Correspondence to:

Arezou Rabzia

Fertility and Infertility Research Center

Kermanshah University of Medical Sciences

Kermanshah, P.O. Box 1568

IRAN

Email: a.rabzia@yahoo.com

Received: 10-07-2012

Accepted: 24-09-2012 